\title{
Analisis Finansial Agroindustri Kelor di PT. Bali Agro Investama
}

\author{
Financial Analysis of Kelor Agroindustry in PT. Bali Agro Investama
}

\author{
Ni Made Losvitasari *) \\ I Wayan Budiasa \\ I.G.A.A. Ambarawati
}

\author{
Magister Agribisnis, Pascasarjana Universitas Udayana, Bali, Indonesia \\ Email : losvitasari17@gmail.com*)
}

\begin{abstract}
Moringa has many benefits for human life including improving critical land, increasing agricultural and livestock products, natural water purification, and new energy sources. The international market demand for Moringa flour is very high, where the raw material comes from Moringa leaves. Currently there is an institution in Bali that is trying to process Moringa leaves into flour, namely PT. Bali Agro Investama (PT. BAI). This study aims to (1) describe the processing of Moringa leaves into flour. And (2) to analyze the financial feasibility of the agro-industrial processing of Moringa leaves into Moringa flour. The results showed that there were five stages of processing moringa leaves into flour, namely (1) washing of moringa leaves with ozonation, (2) draining moringa leaves (3) sorting the damaged moringa leaves, (4) drying the moringa leaves, (5) the moringa leaves using a machine. The business feasibility analysis using the investment criteria obtained the following results: (1) NPV without bank financing and NPV with bank financing is of the same value, which is IDR 628.512.833,00. (2) IRR is 34,55\% when without bank financing and if using bank financing is $41,87 \%$. (3) Net B/C without bank financing is 1,43 and with bank financing of 2,37. (4) Payback period without bank financing for 5,3 years and with bank financing for 8,8 years. The results of sensitivity analysis, this project is sensitive to changes in operating costs and changes in revenue.
\end{abstract}

Keywords : Moringa, financial analysis, sensitivity analysis.

\begin{abstract}
ABSTRAK
Kelor memiliki banyak manfaat bagi kehidupan manusia diantaranya memperbaiki lahan kritis, meningkatkan hasil pertanian dan peternakan, penjernih air alami, dan sumber energi terbaru. Permintaan pasar internasional terhadap tepung kelor sangat tinggi yang dimana bahan bakunya berasal dari daun kelor. Saat ini ada satu lembaga di Bali yang mencoba melakukan pengolahan daun kelor menjadi tepung yaitu PT. Bali Agro Investama (PT. BAI). Penelitian ini bertujuan untuk (1) Mendeskripsikan pengolahan daun kelor menjadi tepung; (2) Menganalisis kelayakan usaha agroindustri pengolahan daun kelor menjadi tepung kelor secara finansial. Hasil penelitian menunjukkan bahwa ada lima tahap pengolahan daun kelor menjadi tepung yaitu (1) pencucian daun kelor dengan ozonisasi, (2) penirisan daun kelor yang telah disortasi, (3) sortasi daun kelor yang rusak, (4) pengeringan daun kelor, (5) penepungan daun kelor menggunakan mesin. Analisis kelayakan usaha menggunakan kriteria investasi didapat hasil yaitu sebagai
\end{abstract}


berikut (1) $N P V$ tanpa pembiayaan bank dan $N P V$ dengan pembiayaan bank bernilai sama yaitu sebesar Rp 628.512.833,00 (2) IRR sebesar 34,55\% ketika tanpa pembiayaan bank dan jika menggunakan pembiayaan bank yaitu sebesar 41,87\%. (3) Net B/C tanpa pembiayaan bank diperoleh 1,43 dan dengan pembiayaan bank sebesar 2,37. (4) Payback period tanpa pembiayaan bank selama 5,3 tahun dan dengan pembiayaan bank selama 8,8 tahun. Berdasarkan hasil analisis sesitivitas, proyek ini sensitif terhadap perubahan biaya operasional dan perubahan penerimaan.

Kata kunci : Kelor, analisis finansial, analisis sensitivitas

\section{PENDAHULUAN}

Tanaman kelor (Moringa oleifera) merupakan salah satu jenis tanaman yang tumbuh di daerah tropis seperti Indonesia. Dewasa ini, kelor digunakan dengan sukses dalam memerangi kekurangan gizi pada anak-anak dan upaya untuk meningkatkan sistem kekebalan tubuh di banyak negara berkembang. Dunia pengobatan tradisional sudah lama menggunakan kelor untuk pengobatan berbagai penyakit, termasuk pemulihan dari kerusakan hati. Kelor memiliki banyak manfaat bagi kehidupan manusia. Beberapa manfaat kelor diantaranya adalah memperbaiki lahan kritis, meningkatkan hasil pertanian dan peternakan, penjernih air alami, dan sumber energi terbaru. Selain itu, kelor juga berkhasiat menyembuhkan penyakit, diantaranya penyeimbang gula darah, meningkatkan kesuburan, mengatasi asam urat dan nyeri sendi, meningkatkan ASI, dan bermanfaat bagi kesehatan kulit. Permintaan pasar internasional terhadap kelor sangatlah tinggi. Salah satunya adalah permintaan tepung kelor yang dimana bahan bakunya berasal dari daun kelor. Tepung kelor memiliki daya tarik tersendiri karena beragam manfaat yang dimiliki. Hal ini terbukti dengan tingginya permintaan tepung kelor oleh perusahaan asal Jepang kepada BUMDes M'rian yaitu sebanyak 40 ton per minggu. Harga tepung kelor inipun tidak main-main yaitu mencapai Rp 250.000/kg. BUMDes M'rian adalah salah satu perusahaan olahan kelor di Indonesia tepatnya di Desa Kufeu, Kabupaten Malaka, Nusa Tenggara Timur. Saat ini pemanfaatan kelor di Indonesia khususnya di Bali masih sangat terbatas. Saat ini ada satu lembaga di Bali yang mencoba melakukan pengolahan daun kelor menjadi tepung. Lembaga tersebut adalah PT. Bali Agro Investama (PT. BAI) yang terletak di Banjar Pangkung Kua, Desa Penyaringan, Kabupaten Jembrana. Berkaitan dengan hal tersebut, penelitian mengenai analisis finansial Agroindustri Kelor di PT. Bali Agro Investama (PT. BAI) perlu dikaji lebih mendalam untuk mengetahui apakah usaha ini layak untuk dilaksanakan atau tidak.

Penelitian ini memiliki beberapa tujuan. Tujuan dari penelitian ini adalah untuk mendeskripsikan pengolahan daun kelor menjadi tepung dan menganalisis kelayakan usaha agroindustri pengolahan daun kelor menjadi tepung kelor secara finansial.

\section{METODOLOGI PENELITIAN}

Penelitian ini dilakukan di PT. Bali Agro Investama (BAI), Desa Penyaringan, Kabupaten Jembrana, Provinsi Bali. Penelitian ini dimulai pada bulan Desember 2020 sampai dengan Juni 2021. Penentuan lokasi penelitian menggunakan teknik purposive (sengaja) yang didasarkan atas beberapa pertimbangan sebagai berikut : (1) PT. Bali Agro Investama (BAI), Desa Penyaringan, Kabupaten Jembrana, Provinsi Bali merupakan agroindustri 
kelor pertama di Bali; (2) Adanya bahan baku yang menunjang proses produksi tepung kelor. Penelitian ini dianalisis secara finansial menggunakan kriteria investasi $N P V$ (Net Present Value), IRR (Internal Rate of Return), Net B/C (Net Benefit Cost Ratio), Payback Period dan analisis sensitivitas. Penelitian ini mengandung dua variabel yaitu variabel manfaat dan biaya. Variabel manfaat mencakup jumlah produksi tepung kelor dan harga produk, sedangkan variabel biaya mencakup biaya investasi dan biaya variabel.

\section{HASIL DAN PEMBAHASAN}

\section{Proses Produksi Tepung Kelor}

Proses produksi tepung kelor memiliki beberapa tahap. Proses produksi tepung kelor yang pertama yaitu pencucian pencucian daun kelor dengan ozonisasi. Daun kelor dimasukkan ke dalam bak pencucian dengan ozonizer untuk menghilangkan kotoran, debu dan juga bagian tanaman lainnya. Tahap selanjutnya adalah daun kelor yang sudah bersih selanjutnya disimpan dalam rak penampungan yang bertujuan untuk meniriskan air yang masih menempel pada daun benar-benar bisa hilang, sehingga pada saat masuk ruang pengering tidak ada air yang terbawa. Tahap ketiga yaitu sortasi. Pada tahap sortasi ini, daun kelor yang segar dan sudah bersih dipisahkan dari ranting dan tangkainya atau dirontokkan. Daun kelor yang berwarna kuning, berbintik putih, dan masih muda atau daun yang rusak harus dipisahkan dan dibuang. Kadar air daun yang sudah yang sudah dirontokkan rata-rata 40,5\%. Tahap selanjutnya yaitu pengeringan. Pengeringan daun kelor dilakukan di dalam ruangan pengering tertutup dengan kelembapan hingga $46 \%$ dan suhu stabil $30-35^{\circ} \mathrm{C}$, atau maksimal pada suhu $38^{\circ} \mathrm{C}$. Pengeringan dilakukan selama tiga hari sampai daun benar-benar kering atau kadar airnya dibawah 5\%. Selama proses pengeringan, daun kelor dihamparkan dalam rak-rak khusus dengan ketebalan maksimal dari $2 \mathrm{~cm}$. Setiap tiga jam sekali, daun kelor dibolak-balik agar kering. Pada saat proses pengeringan, sortasi masih tetap dilakukan untuk memisahkan tangkai daun yang masih terbawa. Proses pengeringan daun kelor ini adalah proses yang vital dari seluruh tahapan proses produksi tepung kelor. Proses pengeringan yang terlalu lama dan kelembapan yang terlalu tinggi akan menyebabkan daun kelor menjadi kuning kecokelatan bahkan tumbuh jamur. Daun kelor kering yang berkualitas baik yaitu berwarna hijau, kering dan tanpa tangkai daun. Daun kelor yang sudah kering selanjutnya disimpan dalam plastik foodgrade yang tertutup rapat. Tahap terakhir pada produksi tepung kelor yaitu penepungan. Penepungan dilakukan dengan bantuan alat diskmill stainless steel yang dimodifikasi khusus untuk menepung dengan kondisi dingin dan menghasilkan debu dari hasil penepungan. Debu inilah yang menjadi tepung kelor dengan kehalusan sampai 500 mesh. Produk kemudian dikemas untuk selanjutkan dipasarkan.

\section{Analisis Finansial}

\section{Net Present Value (NPV)}

Kriteria investasi Net Present Value (NPV) memiliki beberapa ketentuan yaitu jika NPV $=0$ berarti bahwa proyek tidak menguntungkan maupun merugikan. Jika $N P V>0$, maka proyek memberikan keuntungan, serta jika $N P V<0$ berarti bahwa proyek tersebut merugikan. Pada penelitian ini, hasil perhitungan $N P V$ yang tanpa pembiayaan bank maupun dengan pembiayaan bank sama-sama bernilai lebih besar daripada nol. Nilai $N P V$ yang didapat yaitu sebesar Rp 628.512.833,00. Hal ini berarti bahwa proyek agroindustri 
kelor (penepungan daun kelor) layak untuk dijalankan karena menguntungkan. NPV tanpa pembiayaan dan $N P V$ dengan pembiayaan tidak ada selisih dikarenakan oleh penggunaan sembilan angka di belakang koma pada $D F$. Penggunaan sembilan angka di belakang koma pada discount factor untuk meningkatkan ketelitian hasil perhitungan. Semakin banyak angka di belakang koma pada $D F$ yang digunakan maka akan semakin kecil bias hasil pada perhitungan akhir.

\section{Internal Rate of Return (IRR)}

Internal Rate of Return (IRR) menunjukkan tingkat bunga yang membuat NPV sama dengan nol. Suatu proyek dikatakan layak apabila nilai IRR melebihi suku bunga. Suku bunga yang digunakan dalam penelitian ini yaitu sebesar $23,97 \%$ sesuai dengan perhitungan WACC. Pada penelitian ini, didapatkan hasil yaitu IRR sebesar 34,55\% ketika tanpa pembiayaan bank. Hal ini berarti bahwa ketika pabrik penepungan kelor menggunakan modal sendiri tetapi suatu saat berkeinginan untuk menggunakan pembiayaan bank, maka suku bunga maksimal yang mampu dibayar sebesar 34,55\%. Nilai IRR yang didapat jika menggunakan pembiayaan bank yaitu sebesar $41,87 \%$. Artinya jika saat ini pabrik penepungan sudah menggunakan pembiayaan bank, tetapi ditengah perjalanan ingin menambah kredit, maka suku bunga maksimal yang mampu dibayar adalah sebesar 41,87\%. Nilai IRR tanpa pembiayaan bank dan nilai IRR dengan pembiayaan bank sama-sama menunjukkan angka diatas 23,97\%, yang mana artinya bahwa agroindustri kelor (penepungan kelor) di PT. Bali Agro Investama layak untuk dijalankan.

\section{Net Benefit Cost-Ratio (Net B/C)}

Net Benefit-Cost Ratio (Net B/C) merupakan hasil perhitungan perbandingan arus benefit bersih dan biaya yang dihitung nilainya sekarang. Net $B / C$ memiliki ketentuan dimana jika nilainya lebih dari satu, maka proyek layak untuk dijalankan, sedangkan jika nilainya lebih kecil dari satu, maka proyek tidak layak untuk dijalankan. Pada penelitian ini, nilai $\mathrm{Net} B / C$ yang diperoleh yaitu sebesar 1,43 . Nilai ini diperoleh dari perhitungan tanpa pembiayaan bank. Angka ini menunjukkan bahwa Net B/C tanpa pembiayaan bank bernilai lebih besar dari satu, artinya bahwa jika pabrik penepungan kelor dijalankan tanpa pembiayaan bank, maka setiap Rp 1.000,00 biaya yang dikeluarkan akan menghasilkan pendapatan sebesar Rp 1.430,00. Nilai $\mathrm{Net} B / C$ yang diperoleh dari perhitungan dengan menggunakan pembiayaan bank yaitu sebesar 2,37. Ini berarti bahwa jika pabrik penepungan kelor dijalankan dengan pembiayaan bank, maka setiap Rp 1.000,00 biaya yang dikeluarkan akan menghasilkan pendapatan sebesar Rp 2.370,00. Dari kedua perhitungan tersebut, baik yang menggunakan pembiayaan bank ataupun tanpa pembiayaan bank, sama-sama menghasilkan nilai yang lebih besar daripada satu. Hal ini berarti bahwa agroindustri kelor (pabrik penepungan kelor) di PT. Bali Agro Investama layak untuk dilaksanakan.

\section{Payback Period (PP)}

Payback Period $(P P)$ dihitung untuk mengetahui waktu yang diperlukan untuk pengembalian modal investasi. Pada penelitian ini, perhitungan Payback Period $(P P)$ ada dua yaitu perhitungan tanpa pembiayaan bank dan dengan pembiayaan bank. Hasil yang diperoleh dari perhitungan Payback Period tanpa pembiayaan bank yaitu 5,3 tahun. Angka ini berarti bahwa pengembalian modal investasi akan memerlukan waktu selama yaitu 5 tahun 3 bulan 18 hari. Perhitungan Payback Period dengan pembiayaan bank 
diperoleh hasil sebesar 8,8 tahun. Artinya bahwa pengembalian modal investasi memerlukan waktu selama 8 tahun 9 bulan 18 hari. Adanya perbedaan waktu pengembalian modal investasi antara penggunaan pembiayaan bank dan tanpa pembiayaan bank disebabkan oleh pembayaran pokok dan bunga kredit. Semakin banyak modal yang digunakan berasal dari pembiayaan bank, maka semakin lama waktu yang diperlukan untuk pengembalian modal tersebut. Jadi, waktu pengembalian modal investasi yang diperlukan agroindustri kelor (penepungan kelor) di PT. Bali Agro Investama yaitu 5,3 tahun jika tanpa pembiayaan bank dan jika menggunakan pembiayaan diperlukan waktu selama 8,8 tahun. Berdasarkan hasil analisis sensitivitas, agroindustri kelor PT. BAI sensitif terhadap perubahan kenaikan biaya operasional sebesar $10 \%$ dan penurunan penerimaan sebesar $10 \%$.

\section{SIMPULAN DAN SARAN}

\section{Simpulan}

Proses produksi tepung kelor melalui lima tahapan yaitu pencucian daun kelor dengan ozonisasi, penirisan daun kelor yang telah dicuci, sortasi daun kelor yang rusak, pengeringan daun kelor di dalam ruang pengering, dan penepungan daun kelor. Secara finansial, agroindustri kelor di PT. Bali Agro Investama layak untuk didirikan dan dijalankan karena memenuhi syarat kriteria investasi yaitu Net Present Value (NPV) bernilai lebih dari nol, Internal Rate of Return (IRR)) bernilai lebih dari suku bunga yang berlaku, dan Net B/C bernilai lebih dari satu. Berdasarkan hasil analisis sesitivitas, proyek ini sensitif terhadap perubahan biaya operasional dan perubahan penerimaan.

\section{Saran}

Pabrik penepungan kelor di PT. Bali Agro Investama (BAI) sebaiknya segera didirikan dan dijalankan dan hendaknya pendirian pabrik penepungan kelor ini dapat membangkitkan semangat petani khususnya petani kelor dan membuka lapangan pekerjaan.

\section{DAFTAR PUSTAKA}

Arifin. 2016. Pengantar Agroindustri. Bandung : Mujahid Press.

Alifia, F.D., Mubarokah, dan Syarif I.H. 2012. Pengembangan Agroindustri Sangko di Kecamatan Sapekan Kabupaten Sumenep. J-SEP Vol 6 No 3 UPN "Veteran" Jawa Timur.

Aminah, Syarifah, Tezar Ramadhan, dan Muflihani Yanis. 2015. Kandungan Nutrisi dan Sifat Fungsional Tanaman Kelor (Moringa oleifera). Buletin Pertanian Perkotaan Vol.5 No 2. Balai Pengkajian Teknologi Pertanian Jakarta : Jakarta Selatan.

Bey, Hakim. 2010. All Things Moringa. The Story of an Amazing Tree of Life.

Budiasa, I.W. 2011. Studi Kelayakan Pabrik Kelapa Sawit di Kepulauan Riau. Pasific Crest Management. Jakarta - Indonesia. 
Gittinger, J.P. 1986. Analisa Ekonomi Proyek-Proyek Pertanian. Jakarta : UI-Press.

Krisnadi, A.D. 2015. Kelor Super Nutrisi. Pusat Informasi dan Pengembangan Tanaman Kelor Indonesia Lembaga Swadaya Masyarakat Media Peduli Lingkungan (LSMMepeling).

Isnan, Wahyudi dan Nurhaedah M. 2017. Ragam Manfaat Tanaman Kelor (Moringa oleifera Lamk) Bagi Masyarakat. Info Teknis EBONI Vol 14 No 1 : 63-75. Balai Litbang Lingkungan Hidup dan Kehutanan Makasar.

Satori, D'jam'an dan Aan Komariah. 2009. Metodologi Penelitian Kualitatif. Bandung : Alfabeta.

Utomo, M.P. 2018. Analisis Kelayakan Usaha Seduhan Berbahan Dasar Daun Kelor di Desa Brayut Pandowoharjo Sleman. Skripsi. Universitas Atma Jaya Yogyakarta. 